（日本化学会誌, 1975, (3), p. 555～561）

\title{
湿式法によるポリ塩化ビニルの脱塩化水素反応 ${ }^{1)}$
}

\author{
(1974 年 8 月 30 日受理)
}

碇屋 道雄・竹下 三吉*

\begin{abstract}
ポリ塩化ビニル (PVC) を湿式処理による脱塩酸を行ない, 処理条件と脱塩酸生成物の化学的物理的 構造を検討した。

湿式処理は水を媒体とし塩酸の受容体として $\mathrm{NaOH}, \mathrm{KOH}, \mathrm{Ca}(\mathrm{OH})_{2}, \mathrm{Fe}$ 粉末を溶解または懸濁さ せPVC とともにオートクレーブ中で加熱により行なった。PVCは $250 \sim 270^{\circ} \mathrm{C} て ゙$ 完全に脱塩酸され，脱 塩酸生成物は原 PVC と同じ粉粒状であり，その色調は黄色，黄褐色，赤褐色，黑色であった。赤外お よび紫外可視スペクトルの検討から $\mathrm{NaOH}$ 添加物の場合, 脱塩酸生成物は黄色で共役数 6 〜 程度ま でのポリェン，共役ポリエンが酸化された共役ケトン，エーテル橋かけ結合を主体とした化学構造をも ち，その色調はいわゆる酸素による“さらし効果”によるるのである。Fe 添加物の場合は縮合数 4 〜 5 員環程度までの縮合芳香環が化学構造と色調の原因となっていると推定された。脱塩酸のさい $\mathrm{Na}^{+} 1$ オンが共役ポリエン鎖の保護に $\mathrm{Fe}^{2+}$ イオンが芳香環形成に関係しているものと思われた。物理的構造 は細孔容積と細孔分布の測定により検討し, 添加物の PVC 粒子内の拡散が物理的構造に影響している ことが知れた。
\end{abstract}

\section{1 緒}

プラスチック廃棄物の処理特よび利用が社会問題になり，その 解決法がいろいろ提案されている。著者らは処理および利用法の 開発を前提として，ポリ塩化ビニル（以下PVCと略記する）を水 を媒体として使用し，生成塩酸の受容体として添加物存在下湿式 熱処理を行なら方法と湿式処理による脱塩酸生成物の利用を前提 として赤外揖よび紫外可視吸収スペクトル測定, 細孔測定により 化学的および物理的構造に関して若干の知見を得たので報告す る。

PVC の脱塩酸についての研究は基礎的また応用的見地から数 多く行なわれている。基礎的研究の多くは PVC の安定性向上と いら点から研究が進められている。最近では廃棄物処理などに関 連して分解自体にす関心がむけられ，その応用研究は熱分解処理 が主体で, 多くは窒素や空気 (酸素) 雾囲気中の乾式熱分解であ る。さらに基礎研究的にも完全脱塩酸生成物についての化学的構 造に関連した報告は少ない。

完全脱塩酸生成物の処理拉よび化学構造に関連した研究に窒素 や空気 (酸素) 雾囲気中の熱による乾式法による研究2)や液体ア ンモニア中カリウムアミド3)やナトリウムアミド4による均一系3) や不均一系4による報告がある。

前者の乾式法による熱分解では PVC の $200 \sim 250^{\circ} \mathrm{C}$ 間で試料

1）この報文を“プラスチック廃棄物の処理および利用に関す る研究 (第 1 報)”とする.

* 神奈川県工業試験所, 236 横浜市金沢区昭和町

2) 大谷杉郎, 工化, 61, 447(1958).

3) I. V. Astafév, Vysokomolekul. Soedi., 2, 1745(1960).

4）土田英俊，金子正夫，篠原 功，工化，71，1729，1732 （1968）；士田英俊，施 忠男，篠原 功，J. Polym. Sci., $B, 3,643$ (1965),
全体が膨張しながら着色し，ほとんど黒色の色調を示しながら軟 化し相互に固着してしまい, $320^{\circ} \mathrm{C}$ で完全に含有する塩素が脱離 してしまう。脱塩酸生成物の化学構造は生じたポリェンが三次元 的に反応し縮合芳香核が生じ飽和の脂肪族炭素鎖によってつなが った構造となっている。

後者の PVC を液体アンモニア中, カリウムアミド,ナトリウ ムアミドなどで脱塩酸した生成物は赤外, 紫外可視吸収スペクト ル分析, 常磁性共鳴吸収, 元素分析 $(\mathrm{H} / \mathrm{C} \fallingdotseq 1)$ の結果から $+\mathrm{CH}=$ $\mathrm{CH}$ 六の共役系からなる長鎖共役ポリエンの構造といわれる。こ のポリマーは粉末で最初黒色であるが空気中に放置すると酸素に よる酸化のため黒色から褐色, 黄色に脱色していき, また真空中 で加熱すると黒色から赤色になり不安定で純酸素中では爆発的に 発火するといわれている。

\section{2 実験}

\section{1 原 料}

PVC 試料は市販粉末技よび粒状試料を用いた。粉末試料は三 井東圧製のビニクロン $4000 \mathrm{M}$, 重合度 1050,40 メッシュ以下の 純パウダー, 粒状試料は理研ビニール製の $\mathrm{R}-1062 \mathrm{C}$, 厚さ $1 \sim 2$ $\mathrm{mm}$, 直径 $5 \mathrm{~mm}$ の円盤状のほとんど可塑剤を含まない硬質ぺレ ットである。試薬はそのまま実験に供した。

添加物として, 試料特級の $\mathrm{NaOH}, \mathrm{KOH}, \mathrm{Ca}(\mathrm{OH})_{2}$ と電解鉄粉 末を用いた。

\section{2 実験装置および方法}

脱塩酸処理は: $00 \mathrm{ml}$ オートクレーブを使用した。SUS 32 のビ 一カに水 $100 \mathrm{ml}, \mathrm{PVC} 15 \mathrm{~g}$, 添加物を $\mathrm{PVC}$ 中の $\mathrm{HCl}$ と当量を溶 解または揫濁させ，脱気後，オートクレーブ中に入れ内部を窒素 置換したのち，かきまぜながら昇温し，所定温度に達したら所定 時間一定に保持した。終了後ビーカをとりだし，脱塩酸生成物を 
沪過し希塩酸洗浄後水洗し, 空気中で大約乾燥後, 減圧乾燥し測 定に供した。

\section{3 元素分析}

炭水素は三田村理研微量炭水素分析計を用い, 塩素分析はJIS$\mathrm{K} 5581$ により試料 $0.2 \mathrm{~g}$ を精科し, 過剩の $\mathrm{KOH}$ でニッケルル ツポ中で加熱分解後, 温湯に溶解し沪過, 沪液を硝酸銀で電位差 滴定により残塩素量を求めた。

\section{4 スペクトル分析}

赤外吸収スペクトルは日本分光 IR-G 型により $\mathrm{KBr}$ 錠剂法に より濃安 $1 \%$ で測定した。紫外可視吸収スペクトルは脱塩酸生成 物が溶媒不溶なので, 石英セル中にそのまま試料を入れ反射法に より島津自記分光光度計 MPS-5000 型により測定した。

\section{5 細孔分布・細孔容積}

水銀圧入法により細孔直径 $30 \AA$ までの細孔分布と細孔容積を アミンコ 60000 PSI 型ポロシメーターで測定した。

\section{3 結 果と考察}

\section{1 処理温度・時間と脱塩酸率・収率との関係}

粉末試料を使用した場合の処理温度，処理時間と脱塩酸率との 関係を図 $1 ， 2$ に示す。添加物は PVC 中の塩酸量と当量添加し ている。 Fe の添加量は塩化鉄（II）と当量である。添加物は塩酸 の受容体执よび PVC 粒子相互の溶融による固着の防止作用をす る。無添加の場合は PVC 粒子相互が軟化によりカキマゼ羽根の まわりに固着し試料全体がボール状になり脱塩酸処理は昇温途中 で不可能となる。

実験条件内の $230^{\circ} \mathrm{C}$ ではかなり残塩素量は多いが $250,270^{\circ} \mathrm{C}$ ではほとんど完全に脱塩酸される。脱塩酸速度は $230,250^{\circ} \mathrm{C}$ で は $\mathrm{NaOH}>\mathrm{KOH}>\mathrm{Ca}(\mathrm{OH})_{2}>\mathrm{Fe}$ の傾向があるが, $270^{\circ} \mathrm{C}$ ではほ とんど同じになる。完全脱程酸の時点で収率は原料 PVC の塩素 定量から $41.5 \%$ 前後になるはずである。 $\mathrm{NaOH}$ 添加物の場合, $250,270^{\circ} \mathrm{C}$ とも $1 \sim 2 \%$ 収率が多く, $\mathrm{KOH}$ 添加物の場合, $250^{\circ} \mathrm{C}$ で 1 2\% 多いが $270^{\circ} \mathrm{C}$ では $41.5 \%$ 前後である。 $\mathrm{Ca}(\mathrm{OH})_{2}$ 添加 物の場合は 1 2\%低い。Fe 添加物の場合42\%前後である。収率 は脱塩酸量と酸化による酸素量の増加, 炭素-炭素橋かけにより 生じた第三級炭素上の脱水素による減量が相互に関連して決定さ れていると思われる。いずれにしても $250 \sim 270^{\circ} \mathrm{C}$ で完全脱塩酸 される。

$\mathrm{Fe}$ 添加物の場合, 脱塩酸生成物を沪過分離した直後の沪夜は 無色透明で $\mathrm{pH}$ は中性であり， Fe は塩化鉄（II）になって拉り， 生成した塩酸とただちに反応し塩化鉄（II）になって脱塩酸処理 中媒体は中性を保持していると思われる。沪液は空気中に放置す ると酸性になり黄色から黄褐色になるとともに沈殿を生ずる。

\section{2 添加物による脱塩酸生成物の色調之物性}

表 1 に図 1 の場合の処理温度 $270,250^{\circ} \mathrm{C}$ の結果を示す。特徴 的な点は二つあり，その一は，脱塩酸生成物の色調である。添加 物によって黄色, 黄褐色, 赤褐色, 黒色を示している。その二と して脱塩酸生成物が乾式の脱塩酸処理と異なり，原 PVC と同じ 粉末状であり粒子の膨張はほとんどみられない。

元素分析值の合計が 100\%に達しないのは, 主として脱塩酸処 理中, 不純物として存在する酸素や後処理過程での酸化による導 入酸素のためである。 $\mathrm{NaOH}$ 添加物の場合, 含有酸素量が多く,

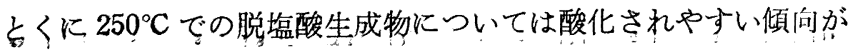

ある。一般に処理温度が高まるほど炭水素の割合が高まり酸化さ れにくい構造になってきていることを示す。 $\mathrm{H} / \mathrm{C}$ 比は $\mathrm{NaOH}$ 添 加物の昜合は 1.2 前後, その他の添加物の場合は 1.1 前後であり 脱塩酸生成物はポリエン系や芳香族系の不飽和系が構造の主体と なっていることが推定される。 $\mathrm{NaOH}$ 添加物の場合, 酸素含量が 高く, $\mathrm{H} / \mathrm{C}$ 比が 1.2 前後のことを考兵ると脱塩酸処理中 $\mathrm{OH}^{-}$の 一部が置換により生成物中に導入されている可能性が考劣られる が， $\mathrm{OH}^{-}$による酸素導入量は生成物中の酸素量を支配するほど

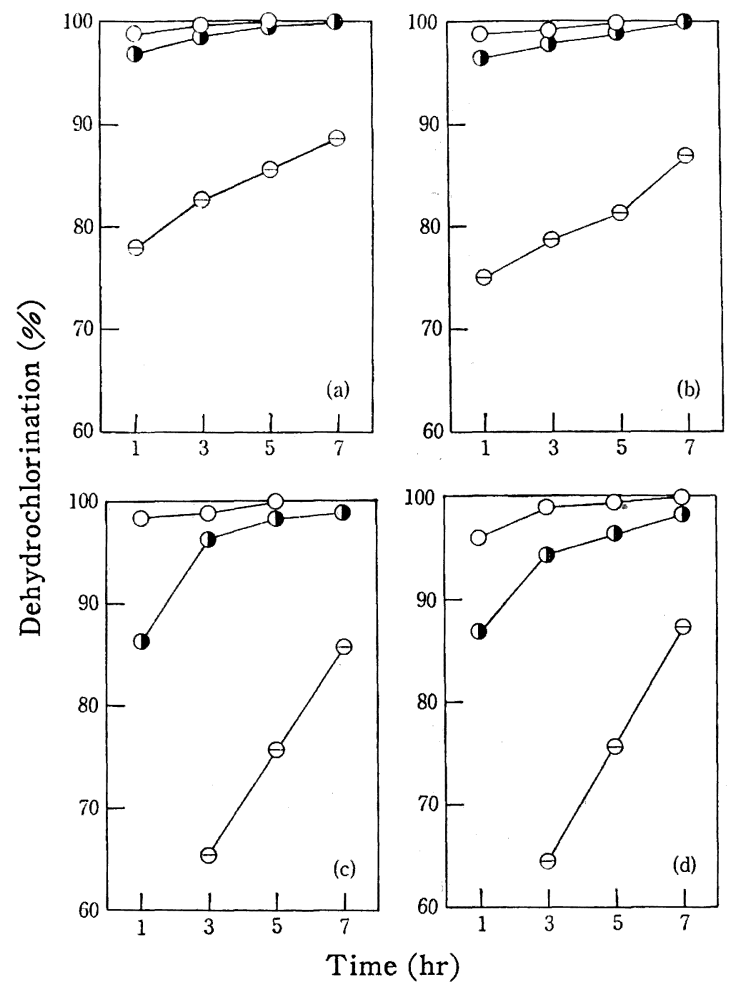

Fig. 1 Relation between extent of dehydrochlorination and treating time

Temperature $\left({ }^{\circ} \mathrm{C}\right)-$

$\bigcirc: 270, \bigcirc: 250, \ominus: 230$

Additive-
(a ) : $\mathrm{NaOH}$, (b) : KOH, (c ) : $\mathrm{Ca}(\mathrm{OH})_{2}$, (d) : $\mathrm{Fe}$

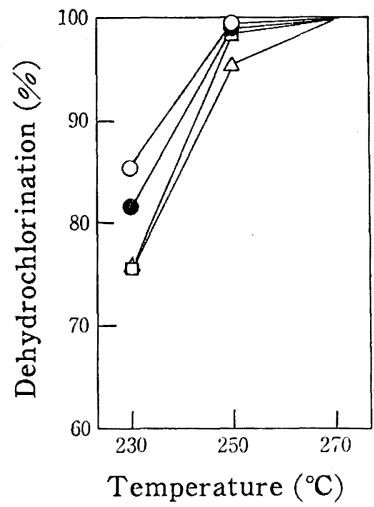

Fig. 2 Relation between extent of dehydrochlorination and treating temperature

Additive-

$\mathrm{O}: \mathrm{NaOH}, \bigcirc: \mathrm{KOH}, \square: \mathrm{Ca}(\mathrm{OH})_{2}, \triangle: \mathrm{Fe}$

Treating time : $5 \mathrm{hr}$ 
Table 1 Typical results of wet dehydrochlorination of PVC

\begin{tabular}{|c|c|c|c|c|c|c|c|}
\hline \multirow[t]{2}{*}{ Additive } & \multirow{2}{*}{$\begin{array}{l}\text { Treating } \\
\text { temperature } \\
\left({ }^{\circ} \mathrm{C}\right)\end{array}$} & \multirow{2}{*}{$\begin{array}{l}\text { Yield } \\
(\%)\end{array}$} & \multicolumn{3}{|c|}{$\begin{array}{c}\text { Analysis (found) } \\
\end{array}$} & \multirow{2}{*}{$\begin{array}{c}\text { Atomic } \\
\text { ratio } \\
\text { H/C }\end{array}$} & \multirow[t]{2}{*}{ Color } \\
\hline & & & $\overparen{C}$ & $\mathrm{H}$ & $\overrightarrow{\mathrm{Cl}}$ & & \\
\hline $\mathrm{NaOH}$ & 250 & 44.2 & 75.05 & 7.70 & 0.32 & 1.23 & Yellow \\
\hline$" 1$ & 270 & 43.6 & 80.04 & 7.92 & 0.08 & 1.19 & $\prime \prime$ \\
\hline $\mathrm{KOH}$ & 250 & 42.7 & 80.33 & 7.62 & 0.41 & 1.13 & Yellowish brown \\
\hline " & 270 & 40.9 & 82.67 & 7.74 & 0.11 & 1.12 & 11 \\
\hline $\mathrm{Ca}(\mathrm{OH})_{2}$ & 250 & 39.8 & 80.73 & 7.33 & 1.76 & 1.09 & Reddish brown \\
\hline "I & 270 & 38.8 & 84.20 & 7.66 & 0.16 & 1.09 & $" \prime$ \\
\hline $\mathrm{Fe}$ & 250 & 42.7 & 81.07 & 7.65 & 1.92 & 1.13 & Black \\
\hline$\prime \prime$ & 270 & 41.8 & 82.68 & 7.70 & 0.40 & 1.11 & $" \prime$ \\
\hline
\end{tabular}

Treating time : $5 \mathrm{hr}$ at $270^{\circ} \mathrm{C}, 7 \mathrm{hr}$ at $250^{\circ} \mathrm{C}$. PVC : Powder.

の量とは考えられない。

脱塩酸生成物の色調, 酸化のされや寸さなどから, $\mathrm{NaOH}$ 添加 物の場合は液体アンモニア中で得られた共役ポリェンの酸化され たもの, $\mathrm{Fe}$ 添加物の場合は乾式の場合, 得られた脱塩酸生成物 に類似の構造のものと予想される。

\section{3 脱塩酸生成物の赤外吸収スペクトルによる検討}

表 1 の $270^{\circ} \mathrm{C}$ の条件下で脱塩酸生成物を同一条件下で $\mathrm{KBr}$ 錠 剂法により測定した結果を図 3 亿示す。残塩素の定量により微量 の塩素は残存するが C-Cl の特性吸収領域である $600 \sim 700 \mathrm{~cm}^{-1}$ には伸縮振動による吸収は現われていない。測定結果からつぎの ことが推定される。

1） $2830,2710,1450 \mathrm{~cm}^{-1}$ の吸収から脂肪族の飽和炭素鎖が 存在する。

2） $\mathrm{Fe}$ 添加物の場合をのぞき，1700と $1600 \mathrm{~cm}^{-1}$ 付近の吸収 から脱塩酸生成物の色調が黄色, 黄褐色, 赤褐色になるにつれて $1600 \mathrm{~cm}^{-1}$ 付近の吸収は深くなり，1630と $1600 \mathrm{~cm}^{-1}$ にわれる。 $1700 \mathrm{~cm}^{-1}$ は逆の傾向を示している。 $1600 \mathrm{~cm}^{-1}$ 付近の吸収は700 $\sim 800 \mathrm{~cm}^{-1}$ の吸収から管香族と共役ポリエンを主体とした吸収と 思われる。 $1700 \mathrm{~cm}^{-1}$ は共役ケトンを主体とした吸収と思わ礼る。 $\mathrm{Fe}$ 添加物の場合は 1700 と $1600 \mathrm{~cm}^{-1}$ に吸収を示すが $1630 \mathrm{~cm}^{-1}$ の吸収ははっきりしない。

3） $3020,1600,1500 \mathrm{~cm}^{-1}$ (肩)の吸収, $700 \sim 870 \mathrm{~cm}^{-1}$ の吸収 から芳香族が予想される。700 および $750 \mathrm{~cm}^{-1}$ が隣接水素 5 個, すなわち一置換体, $750 \mathrm{~cm}^{-1}$ の吸収は隣接水素 4 個, すなわち二 置換体を示し $800 \mathrm{~cm}^{-1}$ から $870 \mathrm{~cm}^{-1}$ の吸収になるにしたがって 多置換体が多くなることを示している。 $\mathrm{NaOH}$ 添加物の場合は, 一置換体または二置換体を主体とし， $\mathrm{KOH}, \mathrm{Ca}(\mathrm{OH})_{2}, \mathrm{Fe}$ 添加物 になるにしたがって多置換体，すなわち縮合芳香核が多くなるこ とを示している。とくに Fe 添加物の場合 $800,870 \mathrm{~cm}^{-1}$ の吸収 が強い。

4) $970 \mathrm{~cm}^{-1}$ の吸収からトランス型の $-\mathrm{CH}=\mathrm{CH}$ - が存在する。

5） $1150,1250,1055 \mathrm{~cm}^{-1}$ の吸収から=C-O-C-または-C-O-Cが存在する。とくに $1055 \mathrm{~cm}^{-1}$ の幅広い吸収は分子間または分子 内の酸素橋かけと思われ $\mathrm{NaOH}, \mathrm{KOH}, \mathrm{Ca}(\mathrm{OH})_{2}, \mathrm{Fe}$ の順に少な くなっている。

6）付着水のためはっきりしないが $3450 \mathrm{~cm}^{-1}$ の吸収から多分 子会合した $-\mathrm{OH}$ が存在する。

7） $1360 \mathrm{~cm}^{-1}$ 付近の吸収は $\mathrm{NaOH}, \mathrm{KOH}$ 添加物の場合と $\mathrm{Ca}$ $(\mathrm{OH})_{2}, \mathrm{Fe}$ 添加物の場合で異なった吸収を示している。この吸収

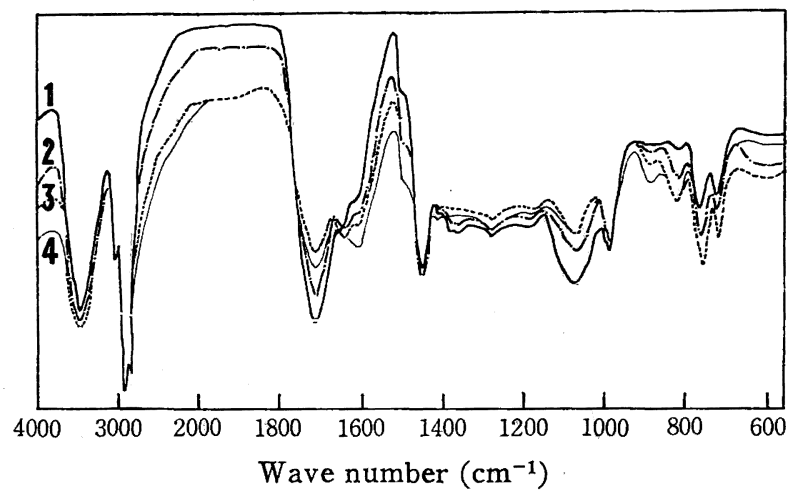

Fig. 3 IR spectra of dehydrochlorination products of PVC at $270^{\circ} \mathrm{C}$ in Table 1

Additive

$$
1: \mathrm{NaOH}, 2: \mathrm{KOH}, 3: \mathrm{Ca}(\mathrm{OH})_{2}, 4: \mathrm{Fe}
$$

は脂環構造が二次元あるいは三次元構造の一部として存在すると 思われる石炭の赤外吸収スペクトルの研究坫から推定すると, 環 状メチレン基の吸収と思われる。 $\mathrm{NaOH}, \mathrm{KOH}$ 添加物による脱塩 酸生成物の場合は分子間脱塩酸または二重結合の一部が付加し完 全に芳香核となっていない一〈二〉など部分的に不飽和二重 結合をるった六員環が含まれていると推定される。

処理温度 $230^{\circ} \mathrm{C}$ の場合原 $\mathrm{PVC}$ に基づく吸収が残っているのを 除くと $250^{\circ} \mathrm{C}$ とも全般的に $270^{\circ} \mathrm{C}$ の場合と吸収の傾向は同じであ る。 $230,250,270^{\circ} \mathrm{C}$ の処理に括ける脱塩酸生成物の $700 \sim 800$ と $1600 \sim 1700 \mathrm{~cm}^{-1}$ 領域の赤外吸収スペクトルを図 4 に示す。 $\mathrm{Ca}$ $(\mathrm{OH})_{2}$ と $\mathrm{Fe}$ 添加物の場合 $270^{\circ} \mathrm{C}$ 処理より $1600 \mathrm{~cm}^{-1}$ と $1630 \mathrm{~cm}^{-1}$ の吸収は弱く肩として現われる。いずれの添加物の場合も700〜 $800 \mathrm{~cm}^{-1}$ の芳香核に基づく吸収が全体的に弱まるが, 700 と 750 $\mathrm{cm}^{-1}$ の吸収は $230,250^{\circ} \mathrm{C}$ でも相対的にかなり強く, 800 と 870 $\mathrm{cm}^{-1}$ の吸収は弱く, $\mathrm{NaOH}, \mathrm{KOH}$ 添加物の場合は $230^{\circ} \mathrm{C}$ ではほ とんど現われない。

以上の結果から $\mathrm{NaOH}$ 添加物による脱塩酸生成物の構造は共 役ポリエンとこれが酸化されて生じた共役ケトン，分子間または 分子内の酸素による橋かけ構造が主体となり，部分的に不飽和二 重結合を含んだ脂環構造または単純な芳香環をるつ構造と推定さ れ， $\mathrm{Fe}$ 添加物の場合は脱塩酸によって生成したポリエンが分子 間执よび分子内で結合して生じた縮合芳香環を主体とした構造

5）藤井修治，横山不二子，燃協誌，37，643(1958). 

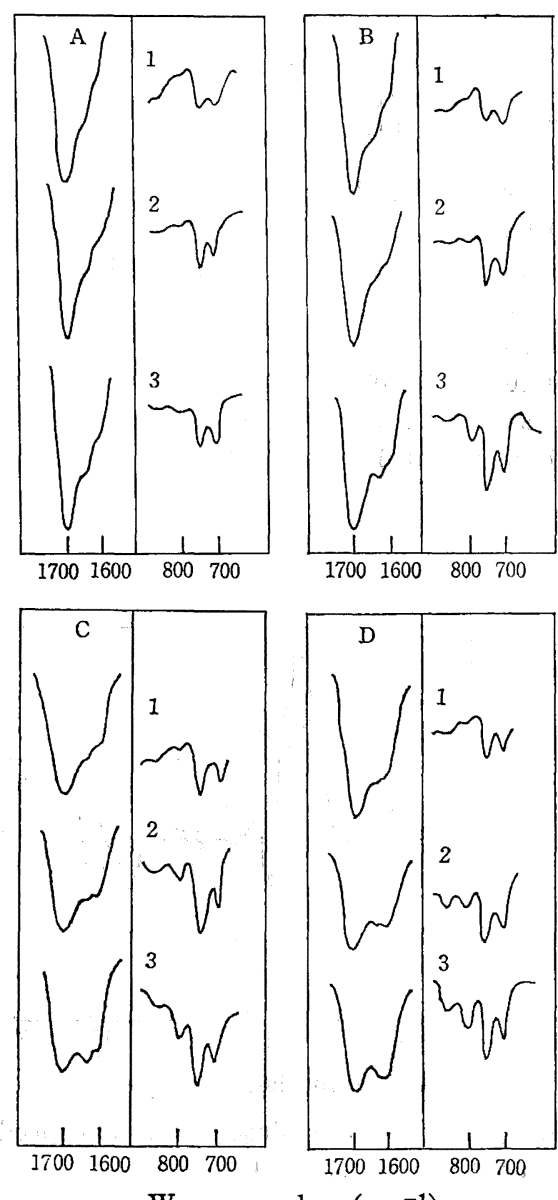

Wave number $\left(\mathrm{cm}^{-1}\right)$

Fig. 4 IR spectra in $1600 \sim 1700 \mathrm{~cm}^{-1}$ and $700 \sim 870 \mathrm{~cm}^{-1}$ region of dehydrochlorination products of $\mathrm{PVC}$

Treating conditions of dehydrochlorination;

Temperature $\left({ }^{\circ} \mathrm{C}\right)$

$1: 230,2: 250,3: 270$

Time (hr)

$1: 7,2: 5,3: 5$

Additive-

$A: \mathrm{NaOH}, \quad \mathrm{B}: \mathrm{KOH}, \mathrm{C}: \mathrm{Ca}(\mathrm{OH})_{2}, \mathrm{D}: \mathrm{Fe}$

に, 部分的にポリエンやこれの酸化によって生じたカルボニル， 分子間や分子内の酸素橋かけ, 脂肪族炭化水素などを含む構造と 推定される。 $\mathrm{KOH}, \mathrm{Ca}(\mathrm{OH})_{2}$ 添加物の場合は $\mathrm{NaOH}$ 添加物と $\mathrm{Fe}$ 添加物の構造の中間に位置し, $\mathrm{KOH}$ 添加物の場合は $\mathrm{NaOH}$ 添加 物の構造に, $\mathrm{Ca}(\mathrm{OH})_{2}$ 添加物の場合は $\mathrm{Fe}$ 添加物の構造に近い。 PVC の空気雾囲気中の完全脱塩酸生成物の赤外吸収スペクト ルによると 1600 と $695 \sim 870 \mathrm{~cm}^{-1}$ 亿芳香族の吸収, $1250 \mathrm{~cm}^{-1}$ K $=\mathrm{C}-\mathrm{O}-\mathrm{C}-$, その他 $-\mathrm{C}=\mathrm{O},-\mathrm{OH}$ 飞上る吸収, 脂肪族炭化水素の吸 収などであるが，1070〜1100 $\mathrm{cm}^{-1}$ に現われるとみられる酸素橋 かけによる吸収は現われていない。

液体アンモニア中のナトリウムアミドによる完全脱塩酸生成物 を空気中に放置すると酸化され退色するが，この酸化されたるの の赤外吸収スペクトルによると，脂肪族扔よび管香族とみられる 吸収が弱く, 酸化の進行につれて共役 $-\mathrm{C}=\mathrm{C}-$ による吸収は減少 しこれに比例して $-\mathrm{C}=0$ に上る吸収は增加する。 $1100 \mathrm{~cm}^{-1}$ の酸 素橋かけの吸収は酸化の進行につれて大きく幅広くなり酸素によ 当橋かけ反応が進行する。長時間空気中に放置した試料でもかな

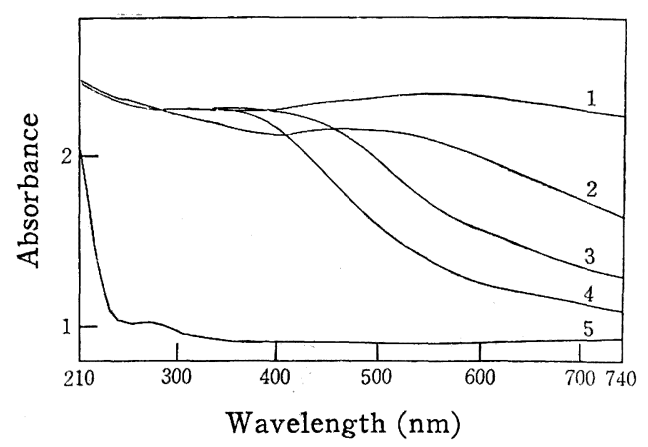

Fig. 5 UV-VIS spectra of dehydrochlorination products of PVC at $270^{\circ} \mathrm{C}$ in Table 1

Additive-

$1: \mathrm{Fe}, 2: \mathrm{Ca}(\mathrm{OH})_{2}, 3: \mathrm{KOH}, 4: \mathrm{NaOH}$,

5 : Original $\mathrm{PVC}$

り $-\mathrm{C}=\mathrm{C}-$ が残っている。

\section{4 紫外可視吸収スペクトルによる検討}

赤外吸収スペクトルの結果から紫外可視吸収の状態を決定する るのは, 共役ポリエン, 芳香核, 共役ケトンが主体となり，これ らが相互に関連して吸収状態が決定される。

図 5 に表 1 の $270^{\circ} \mathrm{C}$ に特ける脱塩酸生成物の紫外可視吸収のス ペクトルを示す。 $\mathrm{NaOH}$ 添加物の場合は $350 \mathrm{~nm}$ ぐらいから吸収 はなだらかな減少を示している。 $\mathrm{KOH}$ 添加物の場合は $\mathrm{NaOH}$ 添 加物と類似の吸収曲線を示しているが長波長側の吸収が大きい。 $\mathrm{Ca}(\mathrm{OH})_{2}$ 添加物の場合は $400 \mathrm{~nm}$ までの徐々に減少する部分と 500 ６00 nm に広い吸収を示し $600 \mathrm{~nm}$ 以下はなだらかに減少し ている。 $\mathrm{Fe}$ 添加物の場合は $420 \mathrm{~nm}$ から $700 \mathrm{~nm}$ に幅広い吸収を 示し, $\mathrm{Ca}(\mathrm{OH})_{2}$ 添加物の場合と類似しているが全体的に完全吸 収に近い。

赤外吸収の結果を参考に Burawoy') や Brade ${ }^{7)}$ の分類にしたが い紫外可視吸収スペクトルを見ると，吸収として現われるのは吸 光係数の大きい $\mathrm{K}$ 吸収帯と $\mathrm{E}$ 吸収帯と思われる。 $\mathrm{NaOH}$ と $\mathrm{KOH}$ 添加物の場合現われた $350 \sim 400 \mathrm{~nm}$ 付近までの吸収は主として $\mathrm{K}$ 吸収带 $\mathrm{Ca}(\mathrm{OH})_{2}$ と $\mathrm{Fe}$ 添加物の場合は $\mathrm{K}$ 吸収帯と $\mathrm{E}_{1}$ 特よび $\mathrm{E}_{2}$ 吸 収帯が現われると思われる。 $\mathrm{NaOH}, \mathrm{KOH}$ 添加物の場合の $\mathrm{K}$ 吸収 帯は共役ポリエン系と共役ポリエノン系を主体とする吸収と思わ れ, $\mathrm{Ca}(\mathrm{OH})_{2}$ と $\mathrm{Fe}$ 添加物の場合は共役ポリエン系と芳香族系を 主体とし $\mathrm{Ca}(\mathrm{OH})_{2}$ 添加物の $470 \mathrm{~nm}, \mathrm{Fe}$ 添加物の $550 \mathrm{~nm}$ を中心 とする吸収帯は縮合芳香環の数が増加するにしたがい長波長側に 深色移動によって生じた多環芳香族の構造をもつ $\mathrm{E}_{2}$ 吸収带と思 われる。

図 6 に脱塩酸処理温度の異なる試料の紫外可視吸収スペクトル を示す。 $\mathrm{NaOH}$ 添加物の場合は短波長側の吸収は $230,250,270$ ${ }^{\circ} \mathrm{C}$ の順に吸収強度は小さく処理温度の低いほど共役鎖長の長い傾 向があり，長波長側の吸収は逆の傾向を示し，処理温度の高いほ ぞ共役鎖長の長い傾向がある。 $\mathrm{KOH}$ 添加物の場合は $\mathrm{NaOH}$ 添加 物と同様の傾向があるが, 短波長, 長波長側とも $\mathrm{NaOH}$ 添加物

6) A. Burawoy, Ber., 63, 3155(1930); J. Chem. Soc., 1939, 1177.

7) E. A. Braude, "U1tra-Violet Light Absorption and the Structure of Organic Molecules", Ann. Reports, Chem, Soc. London (1945) 42, p. 105 130. 


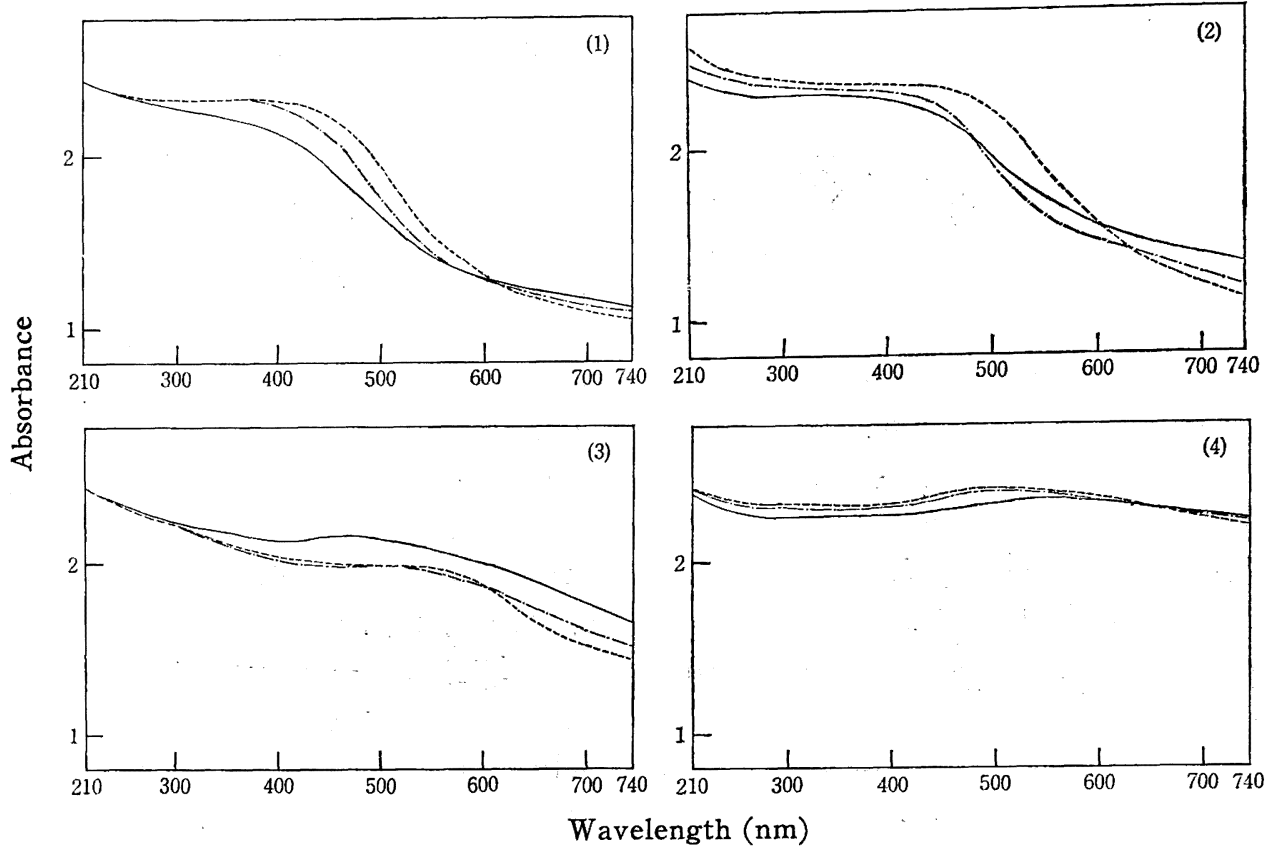

Fig. 6 UV-VIS spectra of dehydrochlorination products of PVC Treating conditions; Additive ; $: 270^{\circ} \mathrm{C}, 5 \mathrm{hr}, \ldots-250^{\circ} \mathrm{C}, 5 \mathrm{hr}, \ldots-230^{\circ} \mathrm{C}, 7 \mathrm{hr}$
(1) : $\mathrm{NaOH}$,
(2) : $\mathrm{KOH}$,
(3): $\mathrm{Ca}(\mathrm{OH})_{2}$,
(4) : Fe

の場合より共役鎖長は長い。 $\mathrm{Ca}(\mathrm{OH})_{2}$ 添加物の場合は，2700 で は短波長側も長波長側も $250,230^{\circ} \mathrm{C}$ よりも吸収は大きいが, 230 $250^{\circ} \mathrm{C}$ の場合は短波長側では大体同じ吸収であるが長波長側では $\mathrm{NaOH}, \mathrm{KOH}$ 添加物の場合と同様に処理温度の高い流と吸収は大 きい。短波長側の吸収は $\mathrm{NaOH}, \mathrm{KOH}$ 添加物の場合と比較して かなり小さいが，長波長側の吸収は大きく共役鎖長は長い傾向に ある。長波長側の吸収は縮合芳香核を中心とする吸収と思われ る。 Fe 添加物の場合はいずれの処理温度の場合も完全吸収に近 く明確な吸収は示さないが $230,250^{\circ} \mathrm{C}$ の場合 $450 \mathrm{~nm}$ 付近に, $270^{\circ} \mathrm{C}$ の場合は $550 \mathrm{~nm}$ 付近に縮合芳香核によるとみられる幅広 い吸収を示している。全体的に $\mathrm{NaOH}, \mathrm{KOH}$ 添加物の場合と同 様厄短波長側の吸収は処理温度の高いほど小さく長波長側ではこ の逆の傾向を示している。

PVC の脱塩酸生成物の紫外可視吸収スペクトルは微細構造を 有することが多いが, 著者らの実験条件内の脱塩酸生成物の紫外 可視吸収スペクトルには微細構造は現われていない。このことは 土田らが液体アンモニア中での PVC の脱塩酸生成物についても 同様の結果を得ておりこれは土田ら年が指摘しているように，共 役鎖長の広い分布によると解釈される。

いずれの添加物の場合も紫外領域では類似の吸収を示しほとん ど完全吸収となる。可視領域では低波長側での吸収は 230，250， $270^{\circ} \mathrm{C}$, 長波長側では $270,250,230^{\circ} \mathrm{C}$ の順に大きく共役鎖長は 長くなる。低波長側では主として共役ポリエン，共役ポリエノン 系の吸収が主体であるが処理温度が低く脱塩酸程度の小さいもの は共役連鎖濃度がうすいため共役連鎖切断が起こり難く生成時の 長い共役連鎖が保持される。このことはとくに残塩素がかなり残 っている $230^{\circ} \mathrm{C}$ の脱塩酸生成物についていえる。処理温度の高い ものは共役連鎖濃度が濃いためか不安定で脱塩酸時や後処理過程
での橋かけなどによる連鎖の切断される割合が多いためと思われ る。長波長側では処理温度の高いほど共役連鎖が長くなっている が，縮合芳香環生成による共役系の安定化のためと思われる。芳 香環は $\mathrm{Fe}, \mathrm{Ca}(\mathrm{OH})_{2}$ 添加物の場合は $230,250^{\circ} \mathrm{C}$ でるかなり生成 していることが紫外可視吸収スペクトルから推定される。

液体アンモニア中での脱塩酸生成物の酸化されたるのの可視吸 収スペクトルと比較すると $\mathrm{NaOH}, \mathrm{KOH}$ 添加物の場合は類似の吸 収曲線となり， $\mathrm{NaOH}, \mathrm{KOH}$ 添加物の場合の脱塩酸生成物は液体 アンモニア中での脱塩酸生成物と類似の構造であることがいえ る。

処理温度 $270^{\circ} \mathrm{C} て ゙ の$ 完全脱塩酸生成物について文献を参考に共 役ポリエン数 ${ }^{8)}$ と縮合芳香環数 ${ }^{9}$ を推定してみると, $\mathrm{NaOH}, \mathrm{KOH}$ 添加物の場合 $400 \sim 450 \mathrm{~nm}$ の K吸収帯より, 構造を単純に $+\mathrm{CH}=$ $\mathrm{CH}$ 方 とし $400 \sim 450 \mathrm{~nm}$ を極大吸収波長とする共役数は $6 〜 8$ 程 度までが推定される。

$\mathrm{KOH}$ 添加物の場合は $\mathrm{NaOH}$ 添加物より共役数の長いるのが多 い。縮合芳香環含量は $\mathrm{Ca}(\mathrm{OH})_{2}$ と $\mathrm{Fe}$ 添加物の場合多いが，多環 芳香核によるとみなされる $\mathrm{Ca}(\mathrm{OH})_{2}$ 添加物の $470 \mathrm{~nm}, \mathrm{Fe}$ 添加物 の $550 \mathrm{~nm}$ の $\mathrm{E}_{2}$ 吸収帯より，縮合芳香環をポリアセン系として 吸収位置から大約の縮合数を推定すると, ナフタセンやペンタセ ソなどの四〜五員環までが主体となっていると思われる。 大谷 ${ }^{9}$ は PVC を窒素雾囲気中 $400 \sim 450^{\circ} \mathrm{C}$ で完全脱塩酸して生

8）日本化学会編，“実験化学講座 1 基礎技術（I ），平山健 三, “紫外スペクトル分析”, 丸善 (1957) p. 24 ; F. Sondheimer, D. A. Ben-Efrain, R. Wolovsky, J. Amer. Chem. Soc., 83, 1675(1961).

9）大谷杉郎, 工化, 61，1324(1958) ; 日本化学会編，“実験 化学講座 1 基碟技術（I )”, 平山健三, “紫外スペクトル 分析”, 丸善 (1957) p. 146. 
じたピッチ状生成物の芳香環の縮合数を推定し三〜五員環芳香族 構造を主体とし，これが数個〜10 個程度が結合した構造として いる。この結果をとにすると $\mathrm{Ca}(\mathrm{OH})_{2}$ や $\mathrm{Fe}$ 添加物の場合す三 〜五環程度の縮合物が基本構造となり $\mathrm{Ca}(\mathrm{OH})_{2}$ 添加物から $\mathrm{Fe}$ 添 加物になるにつれ基本構造が相互に結合する数が多くなるものと 思われる。

\section{5 脱塩酸生成物に対する添加物および共存物の影響}

以上の赤外吸収スペクトル，紫外可視吸収スペクトルの結果を 前提とすると湿式脱塩酸した生成物についてつぎのことがいえ る。 $\mathrm{NaOH}$ 添加物の場合は液体アンモニア中のナトリウムアミド で脱塩酸した生成物の酸化されたものに近い構造であり， Fe 添 加物の場合は, 空気雾囲気中の乾式の脱塩酸生成物に近い構造で ある。 $\mathrm{KOH}$ 添加物の場合は $\mathrm{NaOH}$ 添加物に, $\mathrm{Ca}(\mathrm{OH})_{2}$ 添加物の 場合は Fe 添加物の場合に近い構造をしている。

オートクレーブ中湿式脱塩酸は窒素置換し, 脱塩酸処理を行な ったが，終了後オートクレーブを開くと脱塩酸生成物はすでに黄 色, 黄褐色, 赤褐色, 黑色をしていた。この色調は脱塩酸の程度 には無関係で添加物の種類により決まっていた。赤外特よび紫外 可視吸収スペクトルの結果から，その色調は脱塩酸生成物のポリ エンの酸化程度とポリエンから生じた芳香環含量により決定され ていると思われる。酸化の程度は $\mathrm{NaOH}, \mathrm{KOH}, \mathrm{Ca}(\mathrm{OH})_{2}, \mathrm{Fe}$ の 順で, 芳香環含量はこの逆の傾向を示していた。これらの差異は添 加物の種類による PVC 粒子内の拡散侵透性の差, 添加物和よび 塩酸との反応で生成したイオン, 不純物として室素ガス, 媒体, PVC 粒子中に存在する酸素の関係で決定されると思われる。

添加物の PVC 粒子内の挔散侵透性の羑, すなわち添加物の水 に対する溶解度の差が関係する。 $100^{\circ} \mathrm{C}$ での水に対する添加物の 溶解度は $\mathrm{NaOH}>\mathrm{KOH} \gg \mathrm{Ca}(\mathrm{OH})_{2}$ で $\mathrm{Fe}$ は不溶である。 $270^{\circ} \mathrm{C}$ ま でこの関係が成立しているとすると, 脱塩酸反応はこの順にした がって PVC (固体)-添加物 (溶解)から PVC(固体)-添加物(固体), すなわち固体-液体反応から固体-固体反応となる。このため添加 物の PVC 粒子内部の拡散が問題となり，とくに Fe の場合は PVC 粒子内部に侵入することができず，熱により脱離したHClがPVC 粒子表面付近に拡散してきて，はじめて Fe 粒子と反応する。こ のため乾式熱分解の場合と類似する。 $\mathrm{NaOH}$ 添加物の場合はPVC 分子内の $\mathrm{HCl}$ の脱離した点で $\mathrm{NaOH}$ と反応し，生成した二重結 合と $\mathrm{Na}^{+}$イオンが $\pi$ 錯体を形成し共役系が保護されるが反応末 期には $\mathrm{PVC}$ 粒子内の $\mathrm{NaOH}$ 濃度が問題となり炭素-炭素橋かけ が多少生じる。

芳香環含量は $\mathrm{Fe}$ 添加物の場合が多いが，PVC粒子内の拻散の 問題のため乾式熱分解と類似し炭素-炭素橋かけができやすいが， さらに $\mathrm{HCl}$ との反応で生じた $\mathrm{Fe}^{2+}$ イオンが二重結合と $\pi$ 錯体を 形成し準安定系を形成し六員環をつくりやすくしていると思われ る。 $\mathrm{NaOH}$ 添加物の場合の $\mathrm{Na}^{+}$イオンとの $\pi$ 錯体は $\mathrm{Fe}$ 錯体の場 合ほど安定でなく，分子内また分子間で付加により橋かけ反応を 起こすことは少なく単に共役系を保護しているものと思われる。

芳香環生成の過程をWinslow ${ }^{10)}$ ，大杉2) はつぎのように考察し ている。まず三次元的な炭素一炭素橋かけを生ずる反応として

(1) ポリエン二分子間の付加反応

10) F. H. Winslow, W. O. Baker, W. A. Yager, Proceeding of the First and Second Conferences on Carbon, 93 (1956),
（2）同一分子内のポリエンの付加反応

（3）ポリエン構造の分裂により生じたラジカルに基づく環化 反応

（3）により直接芳香環が生成される。Winslow は（1）の反応に より生じた脂環構造が $400^{\circ} \mathrm{C}$ 以上の急激な重量減少を生ずる温度 で第三級水素の急激な脱離により芳香族化するすのと考光，これ に対して大杉は赤外吸収スペクトルの結果より $320^{\circ} \mathrm{C}$ の温度では （2），（3）の反応により芳香族化する可能性が強く（1）はむし ろ多分子間での飽和の炭素一炭素結合をつくる役割をはたしてい ると推定している。

湿式処理の場合す大杉やWinslow が指摘しているような反応 が生起していると思われ，シクロヘキサジェン環が生成するが， この環状ジエン中の第三級水素は周团の二重結合の影響で非常に 不安定で脱水素反応が $270^{\circ} \mathrm{C}$ 程度でも生起する可能性があり, $\mathrm{Fe}$ 添加物の場合, $\mathrm{Fe}^{2+}$ イオンが炭素-炭素橋かけを生じやすくする とともに，脱水素反応を生起しやすくしている触媒作用や存在す る酸素が脱水素に関与し水として脱離している可能性が考えられ る。

以上は酸素による酸化反応を考虑していないが $\mathrm{Fe}$ 添加物の場 合は，縮合芳香核を主体とした不飽和系による安定化のため酸素 による酸化をうけにくく色調は黒色を示し，基本縮合芳香核間を 結合または側鎖として存在している飽和または不飽和炭素-炭素
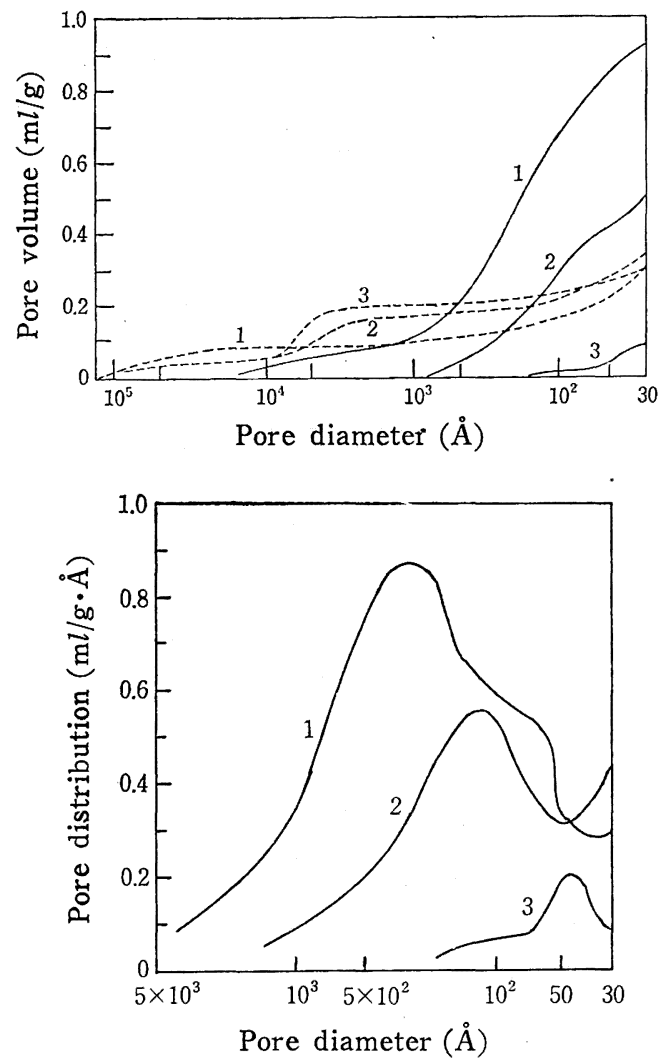

Fig. 7 Relation between pore diameter and pore volume or pore distribution in dehydrochlorination products of PVC

- - - : Products from powdered PVC

: Products from pelleted PVC

Treating conditions of dehydrochlorination : $250^{\circ} \mathrm{C}$, Additive ;

$1: \mathrm{Fe}, \quad 2: \mathrm{NaOH}, \quad 3:$ Original PVC 
鎖が酸化され含酸素基がある程度存在していると思われる。

$\mathrm{NaOH}$ 添加物の場合は $\mathrm{Na}^{+}$イオンのため炭素-炭素橋かけおよ び炭素-炭素橋かけにより生じた環状ジェンからの芳香族化はあ まり起こらず，不純物として存在する酸素のため $-\mathrm{C}=0$ や分子間

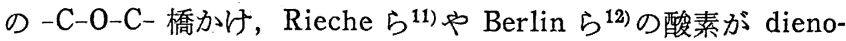
philer としてポリェンに付加し， $>\mathrm{c}\left\langle\begin{array}{l}\mathrm{C}=\mathrm{C} \\ \mathrm{O}-\mathrm{O}\end{array}\right\rangle \mathrm{c}\langle$ のような分子内 橋かけなどが生じ，いわゆる酸素による “さらし効果”によって 共役ポリエン連鎖が切断され浅色化により脱塩酸生成物が黄色を 示していると思われる。

$\mathrm{KOH}, \mathrm{Ca}(\mathrm{OH})_{2}$ 添加物の場合はこの中間と思われ, $\mathrm{KOH}$ 添加 物の場合は $\mathrm{NaOH}$ 添加物に, $\mathrm{Ca}(\mathrm{OH})_{2}$ 添加物の場合は $\mathrm{Fe}$ 添加物 の場合は添加物の場合に近いと思われる。

\section{6 脱塩酸生成物の細孔容積之細孔分布}

3.4 で述べたように添加物の脱塩酸時に括ける拡散性の差によ って脱塩酸のようすが異なり, 化学的拉よび物理的構造に差を与 える。物理的構造に関しては細孔容積と細孔分布に差として現わ れると思われる。とくに粒状 PVC の場合は拡散性が重要な因子 となり差異が大さいと予想される。

図 7 に粉末 PVC と粒状 PVC の脱塩酸生成物の細孔容積と細 孔分布を示す。

11) A. Rieche, A. Grimm, H. Hücke, Kunstoffe, 52, 265, 398(1962).

12) A. A. Berlin, R. M. Seeva, G. I. Kalyaev, E. L. Frankevich, Dokl. Akad. Nauk SSSR, 144, 1042(1962).
粉末 $\mathrm{PVC}$ のついては, 原 $\mathrm{PVC}, \mathrm{NaOH}$ 添加物, $\mathrm{Fe}$ 添加物の 場合とも細孔容積は $0.31 \sim 0.33 \mathrm{~m} l / \mathrm{g}$ で同じくらいである。孔細 分布は原 $P V C$ 試料の場合 $5000 \sim 6000 \AA$ 付近と $50 \AA$ 以下に細孔 が分布して特り， $\mathrm{NaOH}$ 添加物の場合は原 PVC と同様に 5000〜 $6000 \AA$ 付近と $50 \AA$ 以下に細孔が分布し， $50 \AA$ 以下の細孔の割合 が大きくなるが，全体的に原 PVC と同様の傾向を示している。 すなわち原 PVC と同様の物理的構造が保持されている。 Fe 添加 物の場合は $50 \AA$ 以下の割合が原 PVCより大きいことは $\mathrm{NaOH}$ 添 加物の場合と同じであるが，5000～6000Å付近の細孔がなくなり

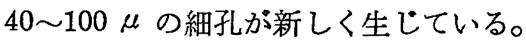

粒状 PVC の場合, 原 PVC, $\mathrm{NaOH}$ 添加物, $\mathrm{Fe}$ 添加物の場合 では細孔容積, 細孔分布とも大変異なっている。原 PVC の細孔 容積は $0.08 \mathrm{ml} / \mathrm{g}$ ，細孔分布は $50 \AA$ 以下に分布を示すだけであ る。 $\mathrm{NaOH}$ 添加物の場合細孔容積は $0.5 \mathrm{ml} / \mathrm{g}, \mathrm{Fe}$ 添加物の場合 は $0.92 \mathrm{ml} / \mathrm{g}$ で $\mathrm{NaOH}$ 添加物の場合の約 2 倍となっている。細孔 分布は $\mathrm{NaOH}$ 添加物の場合 $100 \AA$ 付近と $30 \AA$ 以下に分布のピー クがあり, $\mathrm{Fe}$ 添加物の場合 $300 \sim 500 \AA$ 付近にピークがあり 300 $\sim 50 \AA$ 付近に大部分の細孔が集中している。

このように添加物の種類によって物理的構造が異なる。この物 理的構造の差異は脱塩酸生成物の利用面，とくに気体や液体と反 応をともなら場合重要となる。乾式での脱塩酸生成物は加熱によ りとくに小さい方の細孔が軟化溶融により固着閉塞してしまうた め湿式処理による脱塩酸生成物とは異なると推定される。

（1972 年 10 月, 日本化学会第 27 秋季年会(一部)講演)

\title{
Dehydrochlorination of Poly(vinyl chloride) by Wet Treatment $^{\dagger}$
}

\author{
Michio IKariya and Sankichi Takeshita \\ Industrial Research Institute of Kanagawa Prefecture; Showa- \\ machi, Kanazawa-ku, Yokohama-shi 236 Japan
}

As a part of a series of studies on disposal and utilization of waste plastic, poly (vinyl chloride) (PVC) was dehyrochlorinated by wet treatment. The treating conditions and the chemical and physical structures of the resulting product were investigated.

The wet treatment was carried out in autoclave by heating PVC with an aqueous solution of such as $\mathrm{NaOH}, \mathrm{KOH}$ or $\mathrm{Ca}(\mathrm{OH})_{2}$ or with suspension of $\mathrm{Fe}$ powder as an acceptor of hydrochloric acid. PVC was completely dehydrochlorinated at $250 \sim 270^{\circ} \mathrm{C}$ and the dehydrochlorination product was powdery or granular like the starting PVC and colored yellow, yellowish brown, reddish brown and black. Infrared, ultraviolet and visble spectral studies indicated that the dehydrochlorination product formed in the presence of $\mathrm{NaOH}$ has a chemical structure which is mainly composed of conjugated polyene containing up to $6 \sim 8$ polyenes, ether cross linkages and conjugated ketone resulting from oxidation of conjugated polyene. The tone of yellow color is due to the so-called "bleaching effect" by oxygen. In the presence of Fe, aromatic condensed ring containing up to $3 \sim 5$ rings resulting from conjugated polyene, seems likely to be the origin of its chemical structures and black color. It was inferred that $\mathrm{Na}^{+}$ ions relate to the protection of the conjugated polyene chain and $\mathrm{Fe}^{2+}$ ions to the formation of aromatic ring.

The phyical structure was examined by the measurements of the pore volume and the pore distribution. Diffusion of the additive through PVC particles was found to affect the physical structures.

$\dagger$ Studies on Disposal and Utilization of Waste Plastic. I. 